\title{
1. Territorialism: a first approximation
}

As a planning academic, I cannot cure the ills of the world. But I can deconstruct territorialism, which to my mind contributes to them. To say the least, it stands in the way of us tackling some of the challenges we face.

Nathaniel Lichfield (1983: 5) has pointed out that 'many a private owner (...) has taken a long and wide view of his objective and has practiced resource management on lines which leave little to be desired for the community' - which is as close as you can get to defining what spatial planning is, or should be, about. I pursued this analogy in A Decision-centred View of Environmental Planning (Faludi 1987). Here I focus on one underlying assumption: spatial planning being for well-defined areas over which the authorities responsible hold sway. In a manner of speaking, the areas are the properties of each authority, with its representatives falling all too easily into the habit of talking about their respective territories as 'their country' and about its people as 'their voters'. The further assumption is that the world is divided into territories, each having its own laws and constitution. A famous, or infamous, saying applies: 'Our country! In her intercourse with foreign nations may she always be in the right; but our country, right or wrong!' 1

This book has a different perspective. It arises from studying European spatial planning. This different perspective speaks to Zielonka's neo-medieval order, already referred to. Or, maybe, since that order continued into and even reached its high point during early modernity (Wilson 2017) one should rather call it pre-modern.

1 Ascribed to a US naval officer and commodore, Stephan (or Stephen) Decatur, who uttered this statement at a banquet in his honour after returning from a successful mission against Algeria in April 1816. Often repeated approvingly and disapprovingly, it stands for the unquestioning reification of one's homeland. See: www.thoughtco.com/my-country-right-or-wrong-2831839. 
But neo-medieval is more commonly used and, being counterintuitive - who gets it into his or her mind to think of our age in such terms - more thought-provoking.

Anyhow, at this point suffice it to say - unlike territorialism, and irrespective of whether we label the order neo-medieval or premodern - that other order I am talking about does not assume a mosaic of spatial containers seamlessly filling space, much as plots of land fill a jurisdiction. Since this presumption is constitutive of our system of government, the implications are serious, and not only for spatial planning. They also concern our whole institutional setup - which is why there is uncertainty and, indeed, anxiety about a world without the fixed frames which territorialism affords, a world where each state has exclusive responsibility for its territory.

Such are the thoughts that have come to me while studying European spatial planning for more than 20 years. There are implications for the Union as such. Now, since European integration is so much more important than European planning, why lump them together? The answer it that European planning brings relevant issues to the fore. At least this is how it has worked for me. Planning touches a raw nerve of member states which is their control over their lands, what is also called their territoriality. Nationalism always involves a struggle for land, or an assertion about rights to land (Smith 1981). Put the territoriality of states on the line and you get strong reactions. Even without overtly subscribing to nationalism, members of the Union think and act in terms of, and on behalf of, the lands which they call their own: their territories.

Take for granted that territorialism means conflict; but it can also form the object of reflection. Reflection is what I engage in here, but perhaps in a different way from how readers might expect from an author who has undertaken much research on European spatial planning. I do not sing from the hymn sheet of unreconstructed enthusiasts of European integration. Nor have I returned to the nationalist fold. The two sides of the conflict disagree about who should prevail within a territorial hierarchy, the Union or its members. What they share is their territorialism. Critical of territorialism as such, I keep my distance from both.

This is not my first attempt to come to terms with European spatial planning. With the book mentioned in the Preface - the one I thought would be my last - I reckoned I had come to a resolution. 
As mentioned, it took time to appreciate that yet another book this one - wanted to be written. This was when, along with the paper with the same main title as this book, I held copies of another article, 'European Integration and the Territorial-Administrative Complex', in my hands (Faludi 2016). It challenges territorialism for being a structural and permanent distractor from a form of planning tailor-made for a world without rigid borders. Between them, the two papers clarified for me that fixed units of government for fixed units of space were the problem and that a more encompassing Union, only this time with a larger territory with wider borders thrown around it, was not the solution.

The logical conclusion would be world government. When in the early 1950s Austria was still divided into four occupation zones and the former World War Two Allies held sway, a popular film invoked the scenario of a peaceful protest led by a newly elected (yes, good-looking) federal chancellor against many decades of stalemate over a post-war settlement. People tore up their ID cards in English, French, Russian and German that were required for them to identify themselves to the 'Four in a Jeep', as the allied military police were commonly called. (I had to carry one from the age of 14.) United Nation forces, the plot went, were brought in to quell this rebellion against the international order. Fittingly, the story ended with the Austrian chancellor and the United Nations president, a lady brought in by UFO to quash the revolt, falling in love. Tu felix Austria nube - the full quote in English meaning 'Let others wage war: thou, happy Austria, marry' - said one of the representatives of the Security Council; and thus ended the film released in Austria on 19 November 1952 with the title 1 April 2000 (Marboe 1954). It seems fitting to invoke world government on April Fool's Day.

My turning against territorialism did not come out of thin air. At a seminar in 2008 on 'European Territorial Governance' at Delft University of Technology, Simin Davoudi spoke about her pending co-edited reader with Ian Strange, Conceptions of Space and Place in Spatial Planning (Davoudi and Strange 2009). Links were also forged with Hamburg City University and with Phil Allmendinger and colleagues exploring the notion of soft planning for soft places. Meanwhile, their joint labours have led to yet another fine publication, Soft Spaces in Europe (Allmendinger et al. 2015). We spoke at congresses, including, amongst others, of the Association of European Schools of Planning. My own research on the activities of 
practising European planners went onto the back burner. After the Portuguese, Slovenian and French presidencies of 2007/2008, there was not that much to report. True, in 2011 the Hungarians made a lukewarm and the Poles a valiant but ultimately vain attempt to resuscitate the effort. In neither case was the lack of any long-term success due to the professionalism of the planners. What was responsible was the course of national and European politics. Whatever European planning is going on now is only for partial, often overlapping, areas where cross-border, transnational and recently also macro-regional cooperation continues (Mission Opérationelle Transfrontalière 2017).

I turned my attention to what I thought were fundamental issues: notions of space or territory that underlie planning and European integration alike. Two concepts extremely popular with European planners (and not only them) - multi-level governance and subsidiarity - were the first I got my teeth into (Faludi 2012, 2013). Both assume jurisdictions forming a hierarchy: territorialism. Territorialism not only has an albeit hidden but all-pervasive influence on our lives; it also delimits the scope of spatial planning and of policy making generally. Not least, it delimits also where we should feel we belong.

In a networked world, this can be problematic. 'If the EU is doing badly, well connected as we are, we Swiss are not doing any better,' writes the Tagesanzeiger in a country that, albeit on paper the situation on the ground is different - keeps its distance. ${ }^{2}$ Entering or leaving Switzerland, you may be stopped. The country is part of the Schengen Agreement, so it is not your passport that you have to show; but you may have to pay customs duty, which is also true for goods purchased online. The Swiss keeping out of the Union comes at a cost.

But the thing we do not know is what a world without territorialism would look like. Already more than 20 years ago, the French international relations scholar Bertrand Badie (1995) explored the issue in his book on the end of territories. He pointed out the uncertainties which, if true, the decline of territorialism - surely, it 
would not disappear - would bring with it. Let me reiterate: I admit to being uncertain myself.

Territorialism has fixed itself with an, apparently, impenetrable armour: democratic legitimacy being produced in and by territorial constituencies. On this, the Union appears to fall short. The remedy some propose is for it to become a 'true republic' (Guérot 2016). Others seek to rejuvenate the 'United States of Europe' (CohnBendit and Verhofstad 2012). Yet others single out certain areas in need of further integration. So, there are calls for a Banking Union, an Energy Union and an Environmental Union. But there is little questioning of the assumption that what should be done should be decided by, and in terms of, constituencies that are defined by territory. It follows, or so it appears, that the only way forward is representative democracy at the level of the Union. There are very real concerns about whether this is possible. Discussing them, I am out of my depth; but I think I have at least something to say on the matter.

In some respects, European spatial planning, or at least the idea thereof (it not having much to show for itself), is no different from spatial planning generally. Planners look at the territory of whatever authority is responsible. But, when it comes to European spatial planning, that territory is the sum of the territories of the members of the Union - which is where the trouble starts. European planning hurts itself on the fact that the Union is not a federation, let alone a super-state. What, then, is it? There is no clear answer, but presently member states seek to reassert their sovereignty. To tell the truth, in European spatial planning, they have always done so. Had they failed to do so, voters might have given their political masters a bashing for being too soft on the Union.

Member states guarding their independence even where treaties would seem to give the Union a mandate makes finding answers to far more immediate and pressing issues than planning difficult. Supporters of the Union insist that such problems must be tackled jointly, which in turn meets with indignation from member states and a bewildered public. I myself take a leaf out of the book of Jan Zielonka (2014), whose influence on my thinking I have already acknowledged. As indicated in the Preface, he takes his measure from the Middle Ages. Relations then were less hierarchical and thus more diffuse, which is in fact similar to the present; hence the talk about neo-medievalism. But this does not mean returning to the 
Middle Ages. With neo-medieval spatial planning it is the same. It nowhere implies returning to medieval practices, whatever they may have been.

This point is important because the idea of invoking neomedievalism may be misunderstood. To start with, if it did imply a return to the Middle Ages, which era and respective medieval practices would be meant? The great expert on the Middle Ages Umberto Eco, whose debut novel, The Name of the Rose (1980), has been such a success (no doubt enforced by a magnificent film with Sean Connery as the lead), distinguishes no fewer than ten meanings of Middle Ages (Eco 1986). So, it is incumbent upon me to say what I mean when arguing for neo-medievalism, both in European integration and planning. I mean saying farewell to relying exclusively on modernism's brainchild, territorialism, as well as to associated assumptions about the nation state - those assumptions we all too easily project onto pre-modern times, assuming that the latter merely featured as yet unaccomplished forerunners of our political systems. The pre-modern order was of a different kind, paying less heed to territory and more to functional relations between overlapping centres of authority (Wilson 2017).

These are difficult times, which is maybe why fundamental issues crop up. In respect to one such, Brexit, Brigid Laffan of the European University Institute in Florence challenged centre parties to 'create narratives about what it means to live in an interdependent world (...) We cannot return to a situation of closure, of strong national borders and isolation. That would be an impoverished Europe' (Gordon 2016). It is in this spirit that I offer neo-medievalism as an alternative. Generally speaking, spatial planning - at least the ideology of it - assumes the opposite: that plans respect borders. As far as European planning is concerned, respecting borders was its undoing.

So I present ideas about what spatial planning in an interdependent world might mean. In doing so, I propose to conceive of states as islands in a sea of functional relations. This and other metaphors, all as counter-intuitive as this one, might set European spatial planning - and conceivably European integration generally on a new course. Speculating on such alternatives to the present order might help make sense of an already bewilderingly complex planning practice. In the end, like Molière's Bourgeois gentilhomme 
discovering that he was speaking prose, we might find that we were practising neo-medieval planning all the time.

\section{REFERENCES}

Allmendinger, Phil, Graham Haughton, Jörg Knieling, Frank Othengrafen (eds) (2015), Soft Spaces in Europe: Re-negotiating Governance Boundaries and Borders, London: Routledge.

Badie, Bertrand (1995), La fin des territoires, Paris: Fayard.

Cohn-Bendit, Daniel and Guy Verhofstad (2012), For Europe! Manifesto for a Post-national Revolution in Europe, Munich: Carl Hanser.

Davoudi, Simin and Ian Strange (eds) (2009), Conceptions of Space and Place in Spatial Planning, London: Routledge.

Eco, Umberto (1986), Travels in Hyperreality, San Diego, CA: Harcourt Brace Jovanovich.

Eco, Umberto (1980), The Name of the Rose, San Diego, CA: Harcourt Brace Jovanovich.

Faludi, Andreas (1987), A Decision-centred View of Environmental Planning, Oxford: Pergamon.

Faludi, A. (2012), 'Multi-level (territorial) governance: Three criticisms', Planning Theory \& Practice, 13 (2), 197-211.

Faludi, A. (2013), 'Territorial cohesion, territorialism, territoriality, and soft planning: A critical review', Environment and Planning A: Economy and Space, 45 (6), 1302-17.

Faludi, A. (2016), 'European integration and the Territorial-Administrative Complex', Geografiska Annaler: Series B, Human Geography, 98 (1), 71-80.

Gordon, J. (2016), 'Brigid Laffan on Brexit'. Accessed 24 June 2017 at https://times.eui.eu/brigid-laffan-on-brexit.html.

Guérot, Ulrike (2016), Warum Europa eine Republik werden muss: Eine politische Utopie, Bonn: J.H.W. Dietz.

Marboe, Ernst (1954), yes - oui - o.k. - njet, Vienna: Verlag der Österreichischen Staatsdruckerei.

Lichfield, N. (1983), 'Towards land policy for human survival', International Centre for Land Policy Studies Newsletter, no. 18.

Mission Opérationelle Transfrontalière (2017), Cross-border Territories: Europe's Laboratory, Paris: MOT.

Smith, A.D. (1981), 'States and homelands: The social and geopolitical implications of national territory', Millennium: Journal of International Studies, 10 (3), 187-202.

Wilson, Peter H. (2017), The Holy Roman Empire: A Thousand Years of European History, London: Penguin.

Zielonka, Jan (2014), Is the EU Doomed?, Cambridge: Polity Press. 